\title{
Management and Treatment of Wounds by Projectile from a Firearm in Hand in the Plastic and Reconstructive Surgery Service of the Central Military Hospital in Two Years
}

\author{
Brenda Arcos Vera ${ }^{1 *}$, Felipe Alejandro López Silva², Héctor Adolfo Morales Yépez ${ }^{3}$ \\ ${ }^{1}$ Third-year Resident Surgeon of the Plastic Surgery service and Reconstructive of the Central Military Hospital, CdMx. \\ ${ }^{2}$ Tte. Cor. Surgeon, Head of the Plastic and Reconstructive Surgery Service of Hospital Central Militar. \\ ${ }^{3}$ Senior Surgeon assigned to Plastic and Reconstructive Surgery of the Central Military Hospital, CdMx.
}

*Corresponding Author: Brenda Arcos Vera, Third-year Resident Surgeon of the Plastic Surgery service and Reconstructive of the Central Military Hospital, CdMx.

Received Date: 11 May 2021 | Accepted Date: 25 June 2021 | Published Date: 28 June 2021

Citation: Brenda A Vera, F A L Silva, H A M Yépez. (2021) Management and Treatment of Wounds by Projectile from a Firearm in Hand in the Plastic and Reconstructive Surgery Service of the Central Military Hospital in Two Years. J. Clinical Surgery and Research. 2(3); DOI: 10.31579/2768-2757/016

Copyright: @2021 Brenda Arcos Vera, This is an open-access article distributed under the terms of the Creative Commons Attribution License, which permits unrestricted use, distribution, and reproduction in any medium, provided the original author and source are credited.

\begin{abstract}
Introduction: Gunshot wounds are a major cause of morbidity and lead to serious socioeconomic problems. Wounds often causing severe functional sequelae. Therefore, it is vitally important to provide proper management of these wounds.

Objectives: Define the treatment of gunshot wounds at the Central Military Hospital in the period from March 2019 to March 2021.

Material and Methods: It is a descriptive, retrospective, observational study, RESULTS: Patients who fulfilled the diagnosis presented 3 metacarpal fractures (27.27\%), 2 metacarpal and phalangeal fractures (18.18\%), 2 fractures of phalanges $(18.18 \%), 1$ carpal + metacarpal fractures $(9.09 \%), 3$ with injury only to skin cell tissue without evidence of fractures $(27.27 \%)$. Therapeutic management: 3 patients received external fixator, 2 ORIF, 1 external fixator + ORIF + inguinal flap + bone graft, 1 external fixator + bone graft + ORIF, 0 wound closure, 4 management with wet therapy.

Conclusions: The wounds By firearm in hand are frequent injuries, which merit immediate treatment. This depends on the complexity of the injury for a speedy recovery and integration into the workplace.

Keywords: gunshot wounds
\end{abstract}

\section{Introduction}

To date, gunshot wounds (HPAF) constitute a public health problem in the world. This fact is influenced by multiple factors such as: family disintegration, unemployment, early incorporation into criminal groups, experiences with drugs, uncontrolled dissemination of violent acts through the mass media, as well as greater ease in acquiring weapons [1]. In Each year in the United States, 30,000 to 50,000 people die secondary to HPAF, and they constitute the first cause of death in the first 2 decades of life; furthermore, it is estimated that for each death there are at least 3 disabling injuries. With regard to homicide, it mainly affects men; the most affected age range being 15 to 34 years $[1,2]$

In Mexico, it is evident that the frequency of these injuries has increased [2]. In the last 15 years, injuries from this type of projectile have increased significantly; causing damage through tissue disruption, hemorrhage and infectious processes. These types of wounds are often contaminated with foreign materials such as cloth, dirt, stones, bullets, and splinters [3]. It is therefore important to promptly manage these injuries.

The Central Military Hospital receives both civilian patients who suffer assaults on public roads and active military patients who suffer assaults due to assaults and during confrontations against armed groups. 2 Due to the use of means of protection in the thorax and head, the extremities are areas vulnerable to projectiles and explosions. These are affected with a frequency of $60-80 \%$, and the hand in particular in about $25 \%, 4$ being these infrequent sites. The injuries are generally caused by low speed missiles (pistols), tending to cause complex injuries to the upper extremities6, causing prolonged or permanent disabilities with a personal, 
social and economic impact on young adults and different degrees of severity [7].

\section{Ballistics}

In firearms injuries, three components can be distinguished: entry port, trajectory, and exit site [10].

\section{Entry orifice}

Corresponds to a smaller contused wound; among its characteristics are the carbonaceous halo (false tattoo or smoking) which corresponds fundamentally to the deposit of the elements of deflagration of the gunpowder around the entrance orifice. The flash from the muzzle will cause a burn, so a period of observation is required. If it is an area where the skin is on a bone plane, the following characteristics may be present: Hoffman lesion, stellate lesion, Benassi sign and impression of the cannon on the skin. The "quarter mine" or Hoffman lesion corresponds to a pocket between the skin and the bone; produced by the sudden expansion of the jet of compressed gas after the shot.

\section{Intracorporal trajectory}

During its intracorporeal trajectory, the projectile releases kinetic energy towards the surrounding tissues perpendicular to its trajectory, generating a shock wave that, due to their elasticity, produces a space called "temporary cavity"; but if the shock wave exceeds the resistance of the tissues, they rupture, generating a definitive cavity greater than the diameter of the projectile. If an easily accessible projectile is found, it must be removed.

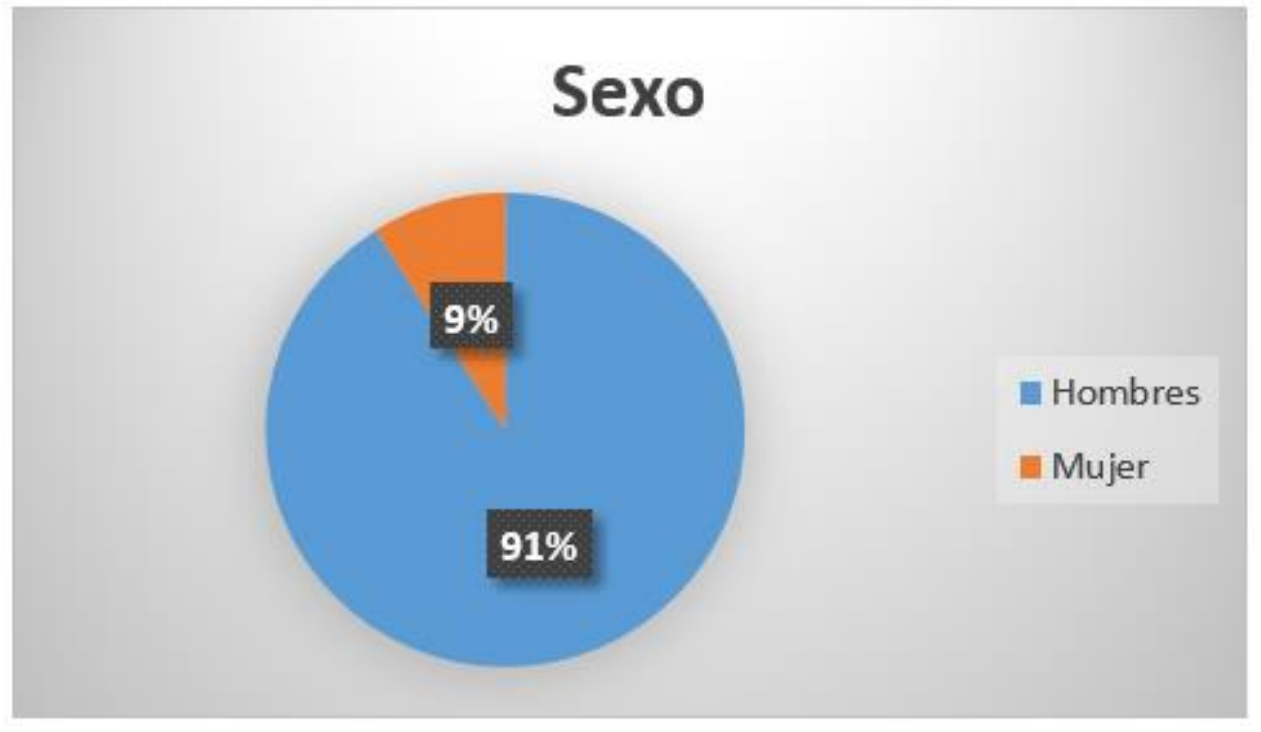

\section{Causahabiencia}

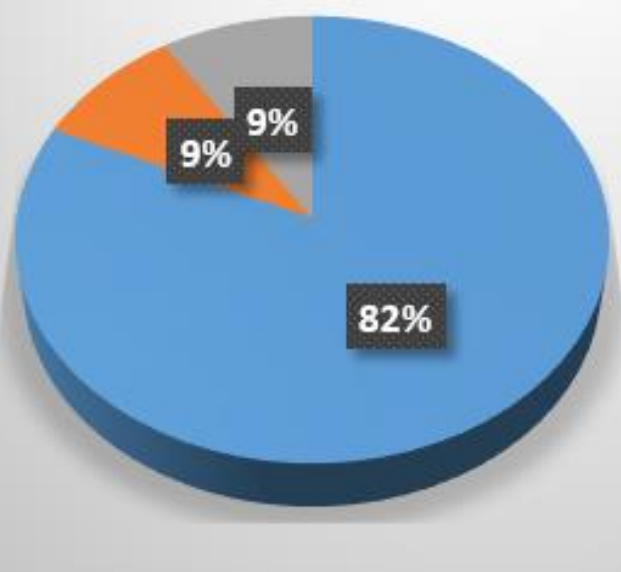

Militar en el activo

- Militar Retirado

merechohabiente 


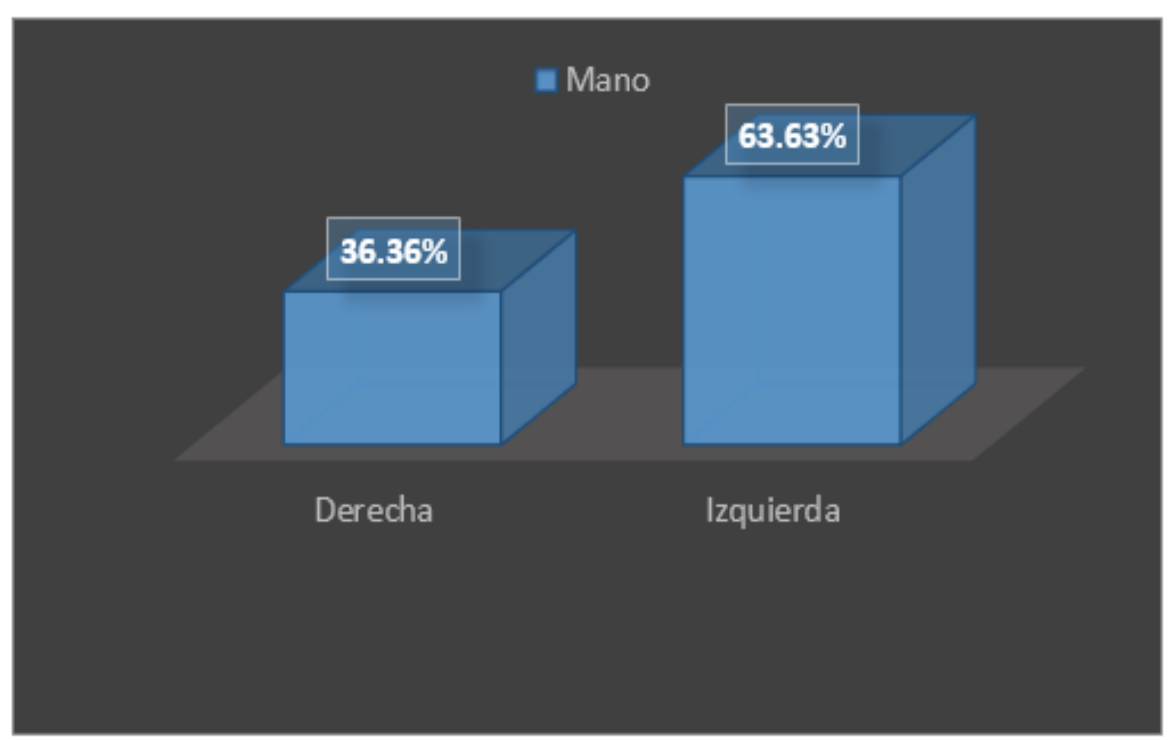

Table 1: Injured hand

\section{LESIONES EN MANO}

- Fracturas de metacarpianos

- Fracturas de metacarpianos y falanges

a fracturas de falanges

Eracturas del carpo y metacarpianos

- Piel sin fracturas

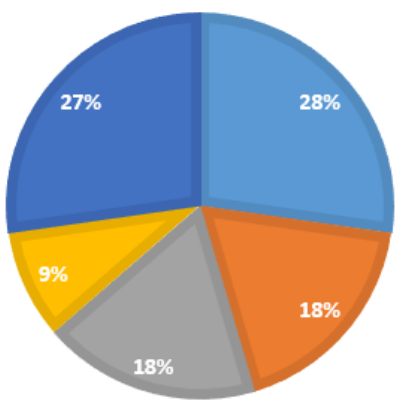

Graph 3: Hand injuries due to projectile wounds from a firearm

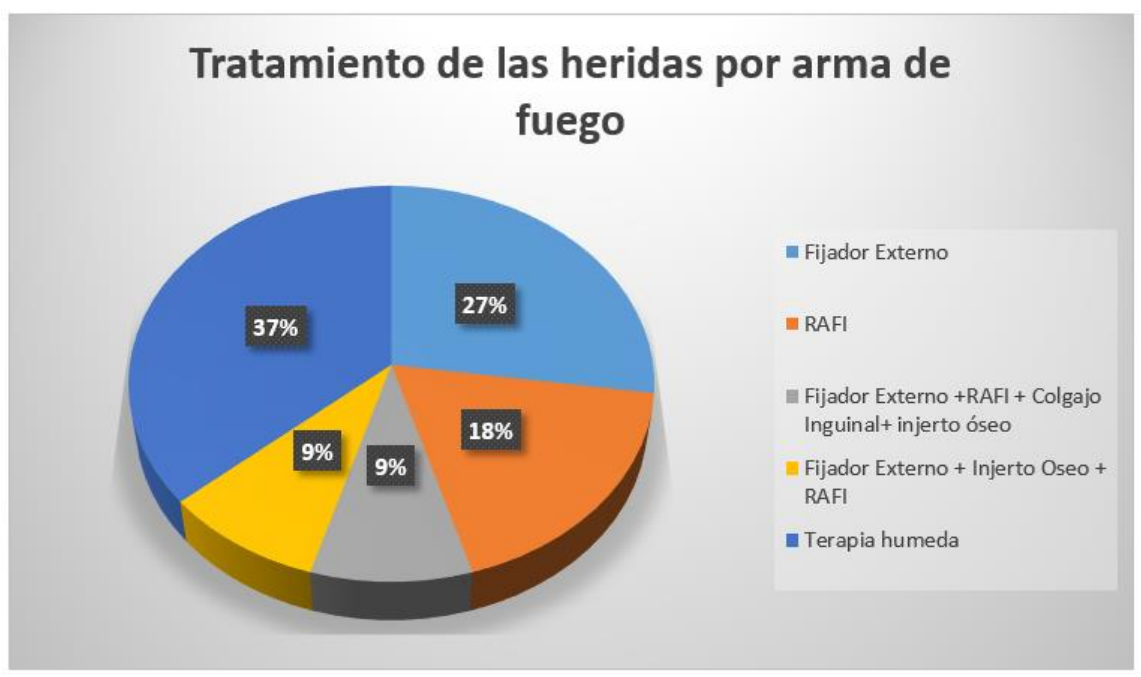

Graph 4: Treatment of gunshot wounds from a firearm 


\section{Outlet hole}

It is formed by the pressure exerted by the projectile from the inside out, everting the skin, the exit orifice tends to be larger and more irregular than the entrance orifice, giving the appearance of having exploded outwards due to the energy they release $[8,10]$.

In the context of wound ballistics, these have 2 classifications, the 1 st one classifies it as Low velocity $<2500 \mathrm{ft} / \mathrm{s}(750 \mathrm{~m} / \mathrm{s})$ and high velocity $=$ or $>2500 \mathrm{ft}$. 2 The $2 \mathrm{nd}$ classification is divided into: Low velocity $<350 \mathrm{~m}$ / s (pistols), intermediate $350-600 \mathrm{~m} / \mathrm{s}$ (shotguns), high velocity 600-700 $\mathrm{m} / \mathrm{s}$ (rifles, 357 revolver, automatic and semi-automatic weapons) causing "explosive effects" $[8,9]$.
Injuries caused by HPAF present multiple variables in terms of their production or ballistics mechanism, the site of the injury, the anatomical regions affected, the degrees of injury produced and the evolution that the affected organs may have. The amount of kinetic energy transferred from the projectile to surrounding tissues, internal organs and directly damaged structures, as well as the final location of the projectile, determines the severity of gunshot projectile wounds. 1 These injuries are complex due to their proximity neurovascular structures and the concurrent participation of various tissues (tendinous, bone or nerve) 3; which require complex and meticulously planned treatments.

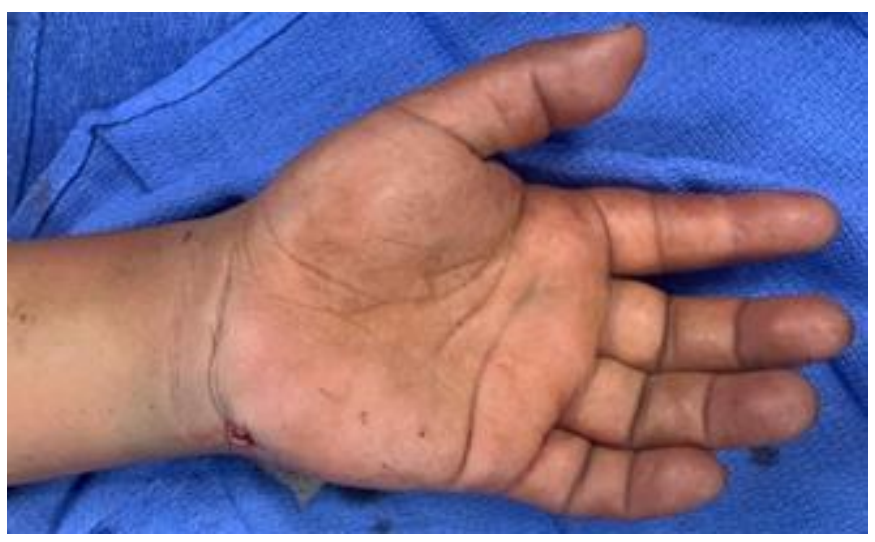

Figure 1: $8 \mathrm{~mm} \times 6 \mathrm{~mm}$ firearm projectile wound entry hole in the left hand in flexor zone IV

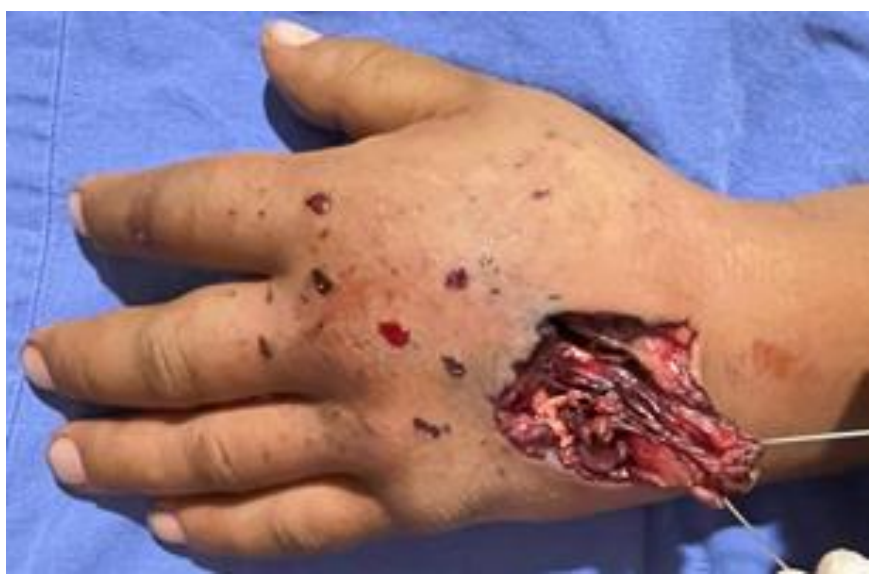

Figure 2: Outlet path with lesion in left hand extensor zone VI causing skin defect of $4 \mathrm{~cm} \times 3 \mathrm{~cm}$

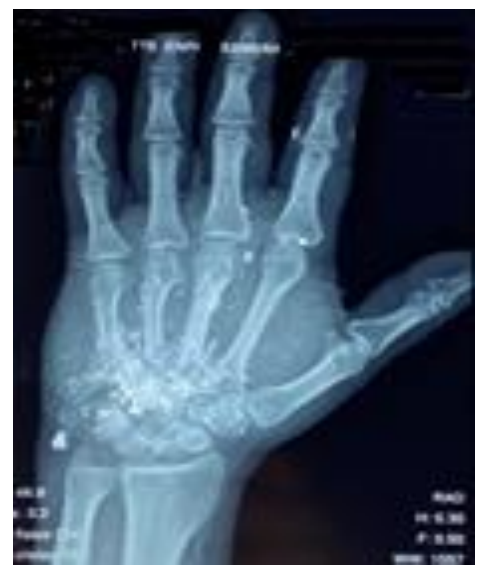




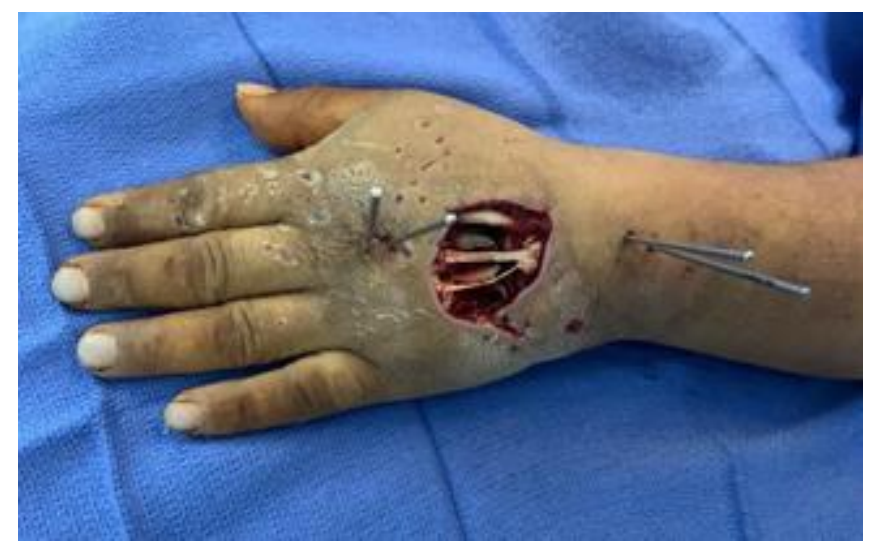

Figure 4: Lesion of $50 \%$ of the extensor tendon of the $3 \mathrm{rd}$, 4th and 5 th fingers, extensor of the 2 nd integral finger of the left hand
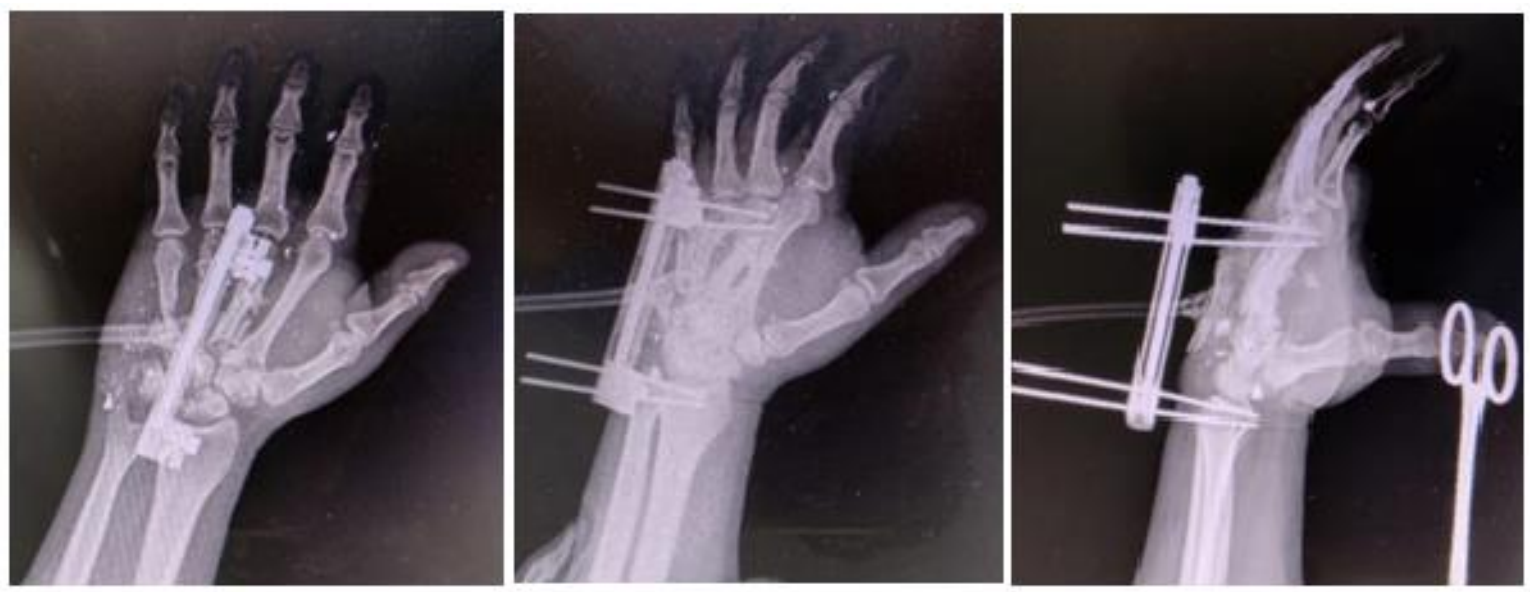

Figure 5: AP, oblique and lateral X-ray control of the $9.5 \mathrm{~cm}$ external fixator in the head of the $3 r d$ metacarpal to the distal radius of the left hand

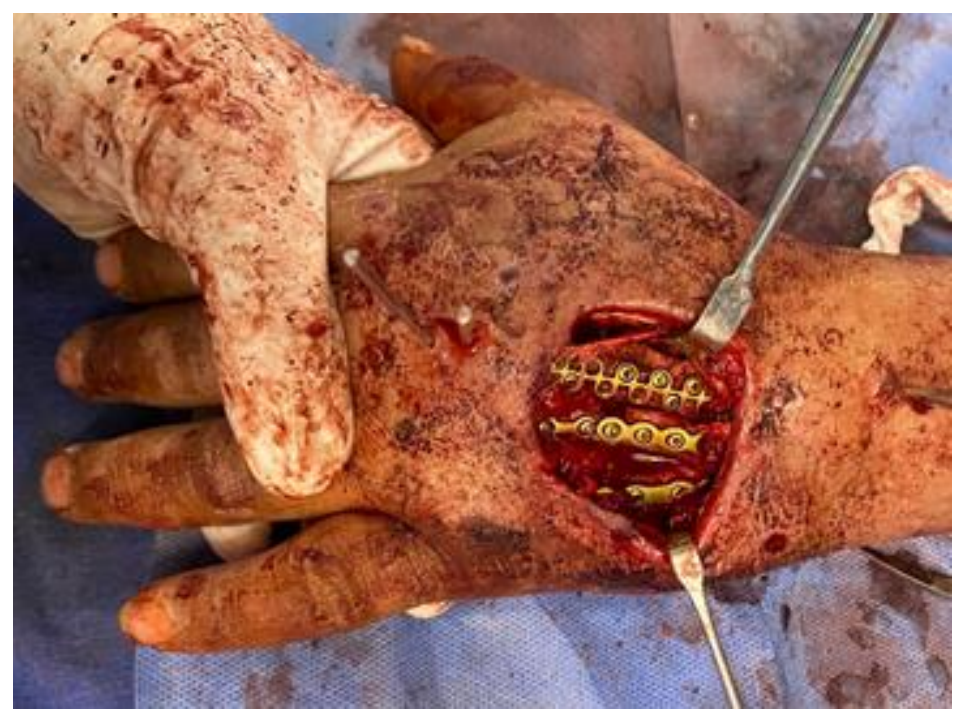

Figure 6: Reconstruction of the left hand with reduction of fractures with bone graft of the left iliac crest (measures $11 \mathrm{~cm}$, for bone defects of the $3 \mathrm{rd}, 4$ th and 5 th metacarpal of $7 \mathrm{~cm}, 5 \mathrm{~cm}$ and $4 \mathrm{~cm}$ ) as well as 4 titanium plates system 2.0 1) 16-hole double to 3rd metacarpal 2) 9-hole T-plate. 3) Simple plate with 4 holes towards 4th metacarpal and 4) with 6 holes towards 5th metacarpal 


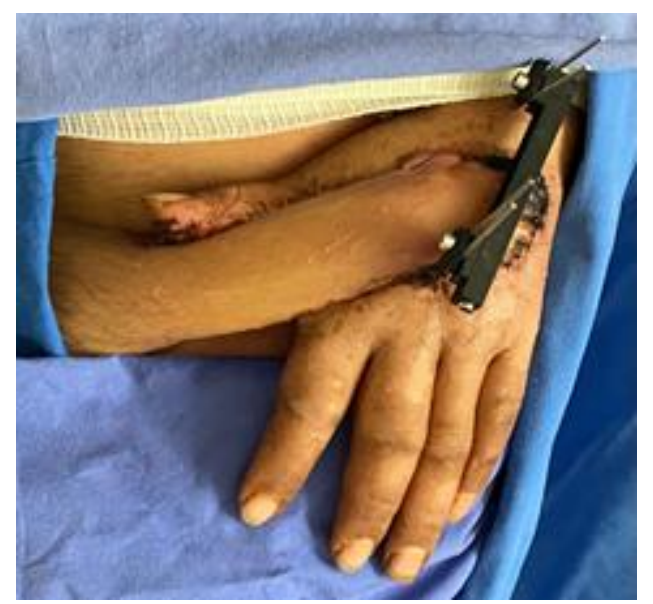

Figure 7: Coverage of the skin defect with a left inguinal fasciocutaneous flap

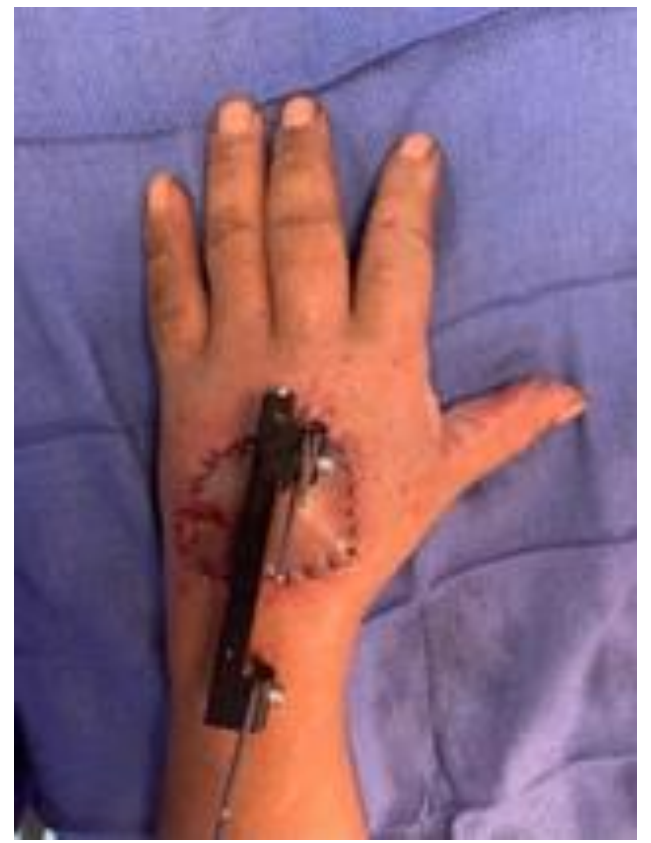

Figure 8: Inguinal Flap Release

\section{References}

1. Canseco Cavazos JC. Palacios Zertuche J. Reyna Zepúlveda F. et al. (2017). Epidemiología de las lesiones por proyectil de arma de fuego en el Hospital Universitario “'Dr. José Eleuterio González" de la Universidad Autónoma de Nuevo León. Cirugía y Cirujanos. 85(1):41-48.

2. García Valadez LR. Hernández Téllez IE. (2015). Castellanos Velazco CA. et al. Epidemiología de las heridas por proyectil de arma de fuego en el Hospital Central Militar de México. Rev Sanid Milit Mex. 69:204-217.

3. Sari A, Ozcelik IB and Bayirli D et al. (2020). Management of upper extremity war injuries in the subacute period: A review of 62 cases. International Journal of the Care of the Injured. 51: 2601-2611.

4. Betancourt GS, Croas FA. (2010). Tratamiento de lesiones traumáticas de las manos producidas por arma de fuego. Revista Cubana de Ortopedia y Traumatología. 24(2):70-80.

5. Pereira C, Boyd B, Olsavshi A, et al. (2012). Outcomes of Complex Gunshot Wounds to the Hand and Wrist A 10- Year
Level I Urban Trauma Center Experience. Annals of Plastic Surgery. 68(4): 374- 377.

6. De la Rosa-Massieu D, González-Sánchez M, Onishi-Sadud W et al. (2014). Lesión severa de mano por proyectil de arma de fuego de alta energía con artrodesis del carpo e injerto sintético de hueso más fijadores externos. Reporte de un caso. Acta Ortopédica Mexicana. 28(4): 240-243.

7. García G, Deichler F, Torres E. (2011). Lesiones por armas de fuego desde la perspectiva médico-criminalística. Rev. Chilena de Cirugía. 63(3): 327-331.

8. Magaña Sánchez IJ, Torres Salazar JJ, García Núñez LM, et al. (2011). Conceptos básicos de balística para el Cirujano General y su aplicación en la evaluación del trauma abdominal. Cirujano General. 33 (1): 48-53.

9. Stefanopoulos PK, Hadjigeorgiou GF, Filippakis K, et al. (2014). Gunshot wounds: A review of ballistics related to penetrating trauma. Journal of Acute Disease. 178-185.

10. Bhandari PS, Maurya S, Mukherjee MK. (2012). Reconstructive challenges in war wounds. Indian Journal of Plastic Surgery. 45(2): 332-339. 
11. Tosti R, Rehman S. (2013). Surgical Management Principles of Gunshot-Related Fractures. Orthop Clin N Am. 44: 529-540.

12. Darabos N, Cesarec M, Grgurovic D et al. (2010). Shotgun Injury to the Arm: A Staged Protocol for Upper Limb Salvage. Military medicine. 175(3): 206-211.

13. Bakhach J, Abu-Sitta G, Dibo S. (2013). Reconstruction of blast injuries of the hand and upper limb. Injury, Int. J. Care Injured. 44: 305-312.

14. Patrick N, Payatakes A. (2017). Vascularized spare parts reconstruction of hand gunshot injury. The Journal of Hand Surgery (Asian-Pacific Volume). 22(3):391-395.

15. Murat Ucak. (2019). Surgical restoration of drop-hand síndrome with tendon transfer in patients injured in the Syrian civil war. Military Medical Research. 6(35): 1-6.

16. Hacikerim S. Ozkaya O, et al. (2011) The practice of plastic surgery in emergency trauma surgery: a retrospective glance at 10,732 patients. Ulus Travma Acil Cerrahi Derg. 17(1):33-40.

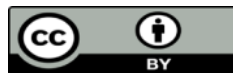

This work is licensed under Creative Commons Attribution 4.0 License

To Submit Your Article Click Here: Submit Article

DOI: $10.31579 / 2768-2757 / 016$

$$
\begin{aligned}
& \text { Ready to submit your research? Choose Auctores and benefit from: } \\
& \text { fast, convenient online submission } \\
& \text { rigorous peer review by experienced research in your field } \\
& \text { rapid publication on acceptance } \\
& \text { authors retain copyrights } \\
& \text { imique DOI for all articles }
\end{aligned}
$$

At Auctores, research is always in progress.

Learn more www.auctoresonline.org/journals/journal-of-clinicalsurgery-and-research 